\title{
The U.S. Supreme Court Speaks on Voluntary School Integration Plans
}

\section{Policy and Practice Implications for Educational Leaders}

\author{
Kathrine J. Gutierrez \\ Lawrence F. Rossow
}

\begin{abstract}
This article addresses important legal issues surrounding voluntary school integration plans and explores policy and practice implications of the Seattle and Louisville cases. School policy guidance for how school districts should create or change their voluntary integration policies is discussed. Further discussion reveals what some school districts around the nation are doing in light of the Seattle/Louisville decision. Additional discussion speaks of future policy possibilities for school districts and educational leaders to consider as a possible solution to creating voluntary school desegregation plans. Practical implications are addressed for middle and secondary school principals as school leaders who must deal with the outcomes produced by school district policies regarding integration plans.
\end{abstract}

Keywords: voluntary school integration plans; school policy implications; school practice implications; legal issues in education

\section{Introduction}

This article addresses important legal issues surrounding voluntary school integration plans and explores policy and practice implications of the Seattle (cited as Parents, 2007) and Louisville (cited as Meredith, 2007) cases in terms of voluntary school integration plans. Select portions of this manuscript include original work from the contributing author, L. F. Rossow in collaboration with L. Connery and N. Schmitt (see Rossow, Connery, \& Schmitt, 2007), in regard to the Seattle/ Louisville cases as excerpted with permission from West's Education Law Reporter and the authors; such portions are reprinted by permission from West, a Thomson Reuters business in this manuscript. These portions include information in the introduction, background of the cases, Supreme Court's rationale in Seattle and Louisville, school policy guidance, future policy possibilities, and conclusion sections of this

Correspondence concerning this article may be sent to: Kathrine J. Gutierrez at kjgutierrez@ou.edu. 
manuscript. For more detailed law discussion on the Seattle/Louisville cases, readers can refer to Rossow et al.'s (2007) article titled "Limitations on Voluntary School Desegregation Plans: The Seattle and Louisville Cases."

In June 2007, in a 5-4 vote, the U.S. Supreme Court reversed the decisions of the Sixth and Ninth Circuit Courts of Appeals in Parents Involved in Community Schools v. Seattle School District No. 1 (2007). The Seattle case was consolidated with Meredith v. Jefferson County Board of Education (2007). The Supreme Court struck down the Seattle and Louisville public schools student assignment plans. Both plans used race as at least one factor in attempting to achieve racial balance in their districts. In so doing, those school districts violated the Equal Protection Clause. The districts had argued that they were following a constitutionally permissible criterion as the basis of their plans-student body diversity. Pursuing student body diversity as a target for racial considerations was upheld a few years earlier in the University of Michigan case Grutter v. Bollinger (Grutter, 2003). However, the Court distinguished Grutter as applying only to higher education (Parents, 2007, citing Grutter, 2003). Therefore, rather than finding that the school districts voluntarily pursued student body diversity, which might have passed constitutional muster, it followed a plan that amounted to only student body ethnicity. In the final analysis, both the Seattle "tiebreaker" and the Louisville "resides" plans were considered racial balancing programs. When the programs were in use, student assignments could ultimately be determined by a single factor-race. Justice Kennedy wrote separately in the plurality opinion in order that it be understood that race can never be considered by school districts that are attempting to develop diversity in the student body. His rationale aligned with the dissents on the point that schools may use "race-conscious measures" as long as race is not the only factor (Parents, 2007, p. 2788, citing Grutter, 2003).

\section{Background of the Cases}

\section{Parents v. Seattle School District No. 1}

Seattle Public Schools has a long and documented history of struggle with racial isolation within its schools. Although approximately $70 \%$ of its residents are White and $30 \%$ are non-White, the public school enrollment shows an inverse relationship with approximately $40 \%$ White students and $60 \%$ non-White students (Parents, 2001). The district includes ten 4 -year public high schools.

Over the past 30 years the district has demonstrated a commitment to attaining and maintaining desegregated schools by voluntarily exploring various measures aimed at ending de facto segregation and providing students access to diverse and equal educational opportunities. Before the start of the 1998-1999 school year the district implemented the current open choice plan, the "Plan," which allows students entering the ninth grade to select any high school in the district. The district assigns 
students to high schools listed as their first choice (Parents, 2005). If too many students list a specific school as their first choice, the school is considered oversubscribed, at which point a series of tiebreakers come into play in the assignment process. The first tiebreaker considers whether the student has a sibling who is already attending the school. The second tiebreaker is used if the oversubscribed high school is racially imbalanced, at which point the race of the student is considered. Both White and non-White students are subjected to the race-based tiebreaker. Up until November 2000, a school was considered "out of balance" if the racial makeup of the school deviates by more than $10 \%$ from the racial makeup of the population of students attending public schools in Seattle, which is approximately 40\% White and 60\% non-White (Parents, p. 1170). In November 2000, a 15\% variance policy was adopted, as well as a "thermostat," where the tiebreaker is "turned off" when the ninth-grade population falls within the $15 \%$ variance, and a student's race is no longer considered in the assignment process. Furthermore, students entering a high school after ninth grade are not subject to the race tiebreaker. After the racial imbalance is corrected, the second tiebreaker is turned off, and the third tiebreaker, proximity of student's home to the school of choice, is implemented. The fourth tiebreaker, a lottery, is used to assign the remaining students to schools (Parents, 2005).

In 2001 a group of parents filed suit against the Seattle school district claiming that the district's "open choice" assignment plan and use of the racial integration tiebreaker violated the Washington Civil Rights Act (Initiative 200), the Equal Protection Clause of the Fourteenth Amendment, and Title VI of the federal Civil Rights Act of 1964. Cross-motions for summary judgment on all claims were filed by the parents and the district (Parents, 2005).

\section{McFarland v. Jefferson County Public Schools}

Jefferson County Public Schools, in Louisville, Kentucky, is the 28th largest public school system in the United States, with an enrollment of approximately 97,000 students in 2003-2004. Comprehensive, specialized, and advanced programs are offered throughout the district's 87 elementary schools, 23 middle schools, and 20 high schools.

Over the past 25 years the school board has sought to maintain fully integrated schools throughout the county (McFarland v. Jefferson County Public Schools, 2004). In April 2001, the Board adopted the currently challenged 2001 Student Assignment Plan (2001 Plan; McFarland, 2004). The 2001 Plan is organized around three basic principles: (a) management of broad racial guidelines, (b) creation of school boundaries or "resides" areas and elementary school clusters, and (c) maximization of student choice through magnet schools, magnet traditional schools, magnet and optional programs, open enrollment, and transfers (McFarland, p. 842). Under the plan, each school is required to seek a Black student enrollment of at least 
$15 \%$ and no more than $50 \%$. Factors such as place of residence, school capacity, program popularity, random draw, and student choices are considered before race comes into play, although in specific cases, whether a student is Black or White could be the determining factor of a student receiving their first, second, third, or fourth choice of school (McFarland, 2004).

\section{The Supreme Courts Rationale in Seattle and Louisville}

The Court reversed the decisions of the lower courts and ruled that both the Seattle and Louisville plans were unconstitutional. The 5-4 decision was not accompanied by a majority opinion. Although the fifth vote came from Justice Kennedy, his opinion was a distinct departure from what would be a plurality opinion. Chief Justice Roberts wrote for the Court. He identified the underlying question to be "whether a public school that had not operated legally segregated schools or has been found to be unitary may choose to classify students by race and rely upon that classification in making school assignments" (Parents, 2007, p. 2746).

The Court began its analysis of the primary issues by establishing that the longstanding approach to the government use of racial classifications is reviewable under strict scrutiny (Parents, 2007, pp. 2751-2752). To satisfy strict scrutiny, the school districts would have to show that the use of individual racial classifications in their plans are (a) narrowly tailored means to achieving a (b) compelling state interest. In applying these two elements, the Sixth and Ninth Circuits concluded that the school districts had a compelling interest in achieving racial balance and that the means employed were sufficiently narrowly tailored. The U.S. Supreme Court disagreed. In reversing both circuits, it noted that they errored when relying on Grutter (Parents, 2007). Grutter (2003) was an affirmative action case. The methods that the University of Michigan used to admit students who could contribute to the diversity of the student body could employ race-conscious considerations as long as it was not attempting to fill a racial quota. However, Seattle and Louisville are school desegregation cases, not affirmative action cases.

Regardless of the differences in goals and context of higher education compared to the public schools, the Parents plans used race as the factor in making student assignment decisions. It relied on race in a nonindividualized, mechanical way. The Court compared the details of the plans with those that were struck down in Grutter's companion case-Gratz v. Bollinger (Parents, 2007, citing Grutter, 2003). Although Gratz came out of the same university, its approach to admissions followed a path that fails strict scrutiny. It did not consider applicants as having a variety of desired characteristics. Rather, it assigned "preference points" to applicants who fell into a certain racial category. In this approach, everything else equal, a student applicant could fail to be admitted because preference points could never be achieved because the student was White. This is the essence of what has become known as 
unconstitutional "reverse discrimination" (see Rossow \& Stefkovich, 2005). The plans in Parents are more like the plans in Gratz than in Grutter.

Anytime the government (in this case, school districts) uses a race factor in the way it functions, it must show that it has a compelling state interest in doing so. If a compelling state interest can be shown, it must next show that the plan is "narrowly tailored" to serve the compelling state interest. For example, the school districts said that they had a compelling state interest in providing a diverse student body. However, the districts' approach amounted to only student body ethnicity. Providing for "diversity" requires more than race considerations. Ironically, for the districts to have expanded their notion of diversity would have caused them to move beyond the purpose of the common schools. As far as the narrow tailoring requirement, the districts did not provide for it. It only counted African Americans in the plan for diversity. A school that had 50\% Asian American and 50\% White students but no African American or Latino students would qualify as balanced. That is not narrow tailoring.

In the final analysis, unless the districts were under court order to desegregate, their approach in being "proactive" about student body race is not permissible. The Seattle school district has never been under court order to desegregate. The Louisville school district had been under court order at one time but has had its decree lifted because it achieved unitary status.

\section{School Policy Guidance}

Where do school districts go from here based on the Seattle/Louisville decision? What are school policy implications for considering racial integration plans? Is there an answer for how school districts should create or change their voluntary integration policies?

The holding in the Seattle and Louisville cases gives a clear direction, albeit in a "what not to do" manner. Districts must now change their existing voluntary school desegregation policies to withstand constitutional challenges. If policies are to avoid the problems of Seattle and Louisville, what modifications should occur?

1. The policy should have a broad-based purpose of achieving student body diversity. The policy must consider a broad effort to achieve "exposure to widely diverse people, cultures, ideas and viewpoints" (Parents, 2007, p. 2754, citing Grutter, 2003 , p. 330). This purpose could then qualify as a constitutionally permissible pursuit of student body diversity. This must be done by avoiding the use of race as the determining factor in making students' school assignments - that would constitute only ethnicity.

2. The policy should be able to produce evidence that it is advancing its stated purpose. Districts must show that there is a compelling interest to have such a policy. Seattle and Louisville argued that there was a broad-based objective of counteracting the negative effects of segregated housing patterns. According to the 
districts, their plans prevented heavy concentrations of non-White students in certain schools. Louisville said it had a broad-based purpose of educating students in a culturally diverse environment. However, the Court noted that neither district had any evidence that their racial identification plans were indeed preventing any segregation from occurring.

3. The policy should be narrowly tailored in its operation. The practical aspects of carrying out the student body diversity policy must use a very broad definition of race and culture for student assignments. The policy must operate to provide integration of White and African American as well as Asian, Latino, and Native American. The goal of broad diversity cannot be achieved by the integration of just White and African American students.

\section{Current Status of School Desegregation Plans}

Presently, there are several hundred school districts in the U.S. that are under court order to desegregate. . . There are approximately 1,000 school systems in the country that presently choose to use race as a factor in student assignment. These schools are directly affected by the PICS ruling [Parents Involved in Community Schools v. Seattle School District No. 1 (2007) and Meredith v. Jefferson County Board of Education (2007)]. The effect of the PICS decision on these schools is that plans that classify or categorize individuals solely on the basis of their race in order to treat those students differently will come under increased scrutiny in the courts. (Mexican American Legal Defense Fund \& Civil Rights Project/Proyecto Derechos Civiles at UCLA [MALDEF \& CRP/PDC], 2008, pp. 5, 7)

This section discusses what some school districts are doing given the implications of the Seattle/Louisville ruling. The CRP/PDC (2008) questioned, "Given the nuanced and somewhat confusing quality of the Court's recommendations, what kind of policy changes have occurred in school districts in the aftermath of the decision?" The CRP/PDC issued a reflection of the Seattle/Louisville cases on June 27, 2008. This reflection outlined three response categories that school districts around the nation are adopting in the wake of the Court's ruling. These categories are:

[1. Race-neutral alternatives] . . . districts [that] have chosen to use race-neutral alternatives in order to continue implementing voluntary integration, [2. Dropped desegregation plans] . . . districts [that] have dropped their desegregation plans altogether, and [3. Adopting plans] . . . school districts [that] have decided to adopt—or are in the process of adopting - plans that consider race in addition to other factors, including language, disability status, and parent income. (CRP/PDC, 2008)

Who are these districts in these categories? In Category 1 (race-neutral alternatives),

. . . school districts in Iowa decided to replace or supplement the use of race in the student assignment process with a consideration of socioeconomic status (SES). Of the 
five Iowa districts committed to revising their diversity plans, Des Moines will solely consider the SES of students, while the other school systems will examine some combination of SES, language status, academic skill level and racial/ethnic background in order to preserve integration options. (CRP/PDC, 2008)

\section{Districts in Category 2 (dropped desegregation plans),}

... [are] comprised mostly of a number of court-ordered school systems who have obtained or are in the process of seeking unitary status in the aftermath of the Seattle/ Louisville decision. Examples from this group include Little Rock, Arkansas, Decatur, Georgia, Wichita, Kansas, and Houston County, Alabama. In Arizona, Tucson Unified School District (TUSD) is in the midst of a protracted legal battle concerning the provisions of a post-unitary plan that would continue to affirm the district's commitment to school diversity. . . . Other districts in this category, like the Seattle Public Schools, were not operating under a court-ordered desegregation plan, but have for the moment decided not to pursue voluntary integration in the wake of the Seattle/Louisville decision. (CRP/PDC, 2008)

In Category 3 (adopting plans),

... two school districts have taken the lead in crafting creative and finely honed integration policies that conform to the new legal climate. Berkeley Unified School District (BUSD), across the bay from San Francisco, California, and Jefferson County Public Schools (JCPS), a merged metropolitan district including Louisville, Kentucky, have each developed student assignment plans that consider the geography of neighborhood opportunities. BUSD pioneered this practice prior to the Seattle/Louisville decision, and has continued to operate under the plan in the aftermath of the ruling. Consequently, this year [2008] Jefferson County school officials developed an assignment plan similar to Berkeley's that recognizes the interaction of geography and race, and recently approved a new diversity plan that will go into effect in 2009. (CRP/PDC, 2008)

What do these plans signal to school districts, school policy makers, school attorneys, and educational leaders? All key players in the formation of school policies should heed the Court's ruling in the Seattle/Louisville decision. Also, voluntary school integration plans have a very strong impact on the students and families who are directly affected by such school district policies.

Additionally, the NAACP Legal Defense and Educational Fund (LDF) and the CRP/PDC have available their 2008 manual titled "Still Looking to the Future: Voluntary K-12 School Integration: A Manual for Parents, Educators and Advocates." In particular, the manual highlights six school districts "that are using alternative approaches to promote racial integration that either do not take race into account or only take account of race as one of many factors" (NAACP LDF \& CRP/PDC, 2008, p. 43). The seven school districts included in the manual as case studies are (a) Berkeley Unified School District (BUSD), California; (b) Wake County, North Carolina; 
(c) Charlotte-Mecklenburg Schools (CMS), North Carolina; (d) Cambridge Public Schools (CPS), Massachusetts; (e) Omaha Public Schools, Nebraska; (f) San Francisco Unified School District, California; and (g) St. Louis Public Schools, Missouri (NAACP LDF \& CRP/PDC, 2008). The current circumstances of these school districts make understanding the nature of school integration plans an important topic for school districts across the nation to consider, especially for those who may be still grappling with the Court's ruling and school policy implications of the Seattle/Louisville decision. It is important to note here that according to MALDEF and CRP/PDC (2008),

if your school district is under court order to desegregate, the PICS ruling has no effect on your school district as long as the court order is in place. However, when the court order is lifted, the PICS ruling will apply to your school district. (p. 1)

So, why is it important for school districts to consider the ruling and take some form of policy action? According to MALDEF and CRP/PDC (2008):

If your school district is not under court order to desegregate, but has recognized the benefits of racial integration and has chosen to implement integration policies, the PICS [Parents Involved in Community Schools v. Seattle School District No. 1 (2007) and Meredith v. Jefferson County Board of Education (2007)] ruling has significant implications for your school district. The PICS ruling limits voluntary desegregation plans. . . . In addition to increased school segregation by race and poverty, there may also be a corresponding increase in school districts subject to state sanctions for the low academic achievement levels of racially isolated minorities. (p. 1)

At the time of this writing, here is a look at additional on goings in other areas of the nation that includes activities in Des Moines, Iowa:

A new open enrollment policy based on family income rather than race has significantly decreased the number of Des Moines students who will be allowed to transfer out of the district, new data show. . . The Des Moines school board voted in late February [2008] to change the criteria for open enrollment. The change was based on a U.S. Supreme Court ruling that schools could no longer use race exclusively as a means to achieve desegregation. Des Moines officials decided to define "minority" by family income - specifically, whether a family qualifies for the government's free- or reduced-price lunch program. . . . Essentially, the only Des Moines students now allowed to transfer out are low-income students or those with siblings who have already left the district. All others must stay, or their families must move to another district. (Hawkins, 2008)

In Memphis, Tennessee, Thomas (2008) noted:

Shelby County Schools remain under a court-ordered desegregation plan while the Memphis City Schools system is not, and has not been since 1999. There are documented 
benefits for integrated schools - for example, black students at integrated schools score better on standardized tests than black students at racially isolated schools. The quality of teachers tends to be higher at schools with an ethnically diverse student body. And white and black students report being more tolerant of others at more integrated schools. "I think it's all really valuable," Daniel Kiel, an adjunct law professor at the University of Memphis and graduate of the Memphis City Schools, says of truly integrated schools. ... But without considerable busing, city-county consolidation and the consternation it would inevitably cause, "Do I think it's achievable in Memphis? No."

In Napa, California, Burchyns (2008) noted:

The Napa Valley Unified school board has approved including socioeconomic status of students in studying high school attendance boundary options. The future opening of American Canyon High School, slated for 2010, has triggered the analysis. The board voted unanimously Thursday [April 3, 2008] . . to approve a task force's recommendation to use socioeconomic status as the primary measure of diversity in district schools.

In Stamford, Connecticut, Cowan (2008) reported:

Schools in Hartford and 22 of its suburbs would be encouraged to open more classroom seats to children from outside their neighborhoods in order to increase racial diversity, under a tentative settlement reached Friday [April 4, 2008] in a decades-old desegregation case. The settlement, which still requires the approval of Connecticut legislators and the state court handling the dispute, outlines a five-year plan whose goal is to get at least 41 percent of Hartford's minority students into schools where enrollments are no more than three-quarters minority.

\section{Future Policy Possibilities}

Although the holding and rationale of the plurality is the law of the land, what Justice Kennedy wrote in his concurrence deserves attention. His was the swing vote in this case. Some observers believe that the next time there is a challenge to a voluntary school desegregation policy, Kennedy's contributions providing guidance in Seattle and Louisville may carry the day. Theodore Shaw, president of the NAACP Legal Defense Fund, has said "I am grateful for the sliver of hope that Justice Kennedy's opinion holds out. He refused to join the most radical view, which would have made it impossible for a school district to do anything about racial segregation" (Lehrer, 2006). Those happy about the parents' victory conclude that the Court was saying that it is wrong for Seattle and Louisville to tell children that where they can go to school depends on their skin color (Lehrer, 2006).

Recall that Justice Kennedy noted that school districts that are attempting to achieve a diverse student body are allowed to look at race-conscious measures, but 
race cannot be the only factor. He suggested alternative ways for districts to be permissibly race conscious, for example: strategic building of schools in areas that would draw from integrated areas, doing targeting recruitment of students and teachers, or allocating resources for special programs.

1. Have a goal that is democratic. The stated purposes of the Seattle and Louisville plans were both proactive and preventative. They promoted democracy by teaching children of different races to get along with one another and thereby be prepared to live in an ever-increasing pluralistic society. In addition districts could show the racial balancing would help prevent racial isolation and prevent the resegregation of the district. The district might call this its interest in student body diversity. The dissent and Kennedy saw these types of goals as serving a compelling state interest.

2. Have a goal that is educational. The goals in Seattle and Louisville promoted minorities in their striving to attain higher levels of achievement. The dissent and Kennedy had sufficient confidence in the available social scientific studies to support the notion that this type of goal (along with the democratic element) served a compelling state interest.

3. Have operational details that are multiphasic. The operational aspects of the plan must avoid using race as a single factor in making student assignments. Instead the plan should employ a broad range of student characteristics in making the assignment to a school. Each student should be treated as an individual. Kennedy said that if Seattle and Louisville had refrained from using a mechanical race formula, the outcome might have been different: "If those students were considered for a whole range of their talents and school needs with race as just one consideration, Grutter would have some application" (Parents, 2007, p. 2794).

Justice Kennedy outlined the aspects of a plan that could work. He said districts could have plans that showed they were:

1. including strategic site selection of new schools,

2. drawing attendance zones with general recognition of the demographics of neighborhoods,

3. allocating resources for special programs,

4. recruiting students and faculty in a targeted fashion, and

5. tracking enrollments, performance, and other statistics by race (Parents, 2007, p. 2828).

These are examples of what could be done to meet the "narrowly tailored" component of strict scrutiny. If Justice Breyer's opinion is carefully considered, one might say a school district has wide latitude in the development of plans. Citing Swann v. Charlotte-Mecklenberg Board of Education (1971) in his dissent, he notes that Chief Justice Burger wrote:

School authorities are traditionally charged with broad power to formulate and implement educational policy and might well conclude, for example, that in order to prepare 
students to live in a pluralistic society each school should have a prescribed ratio of Negro to white students reflecting the proportion for the district as a whole. To do this as an educational policy is within the broad discretionary powers of school authorities.

(Parents, 2007, p. 2801; italics in the original, quoting Swann, 1971, p. 16)

Between the examples for success given by Justice Kennedy and the "wide latitude" position of the dissent, it should be possible for districts to create or change current policies. Of course, only additional litigation will tell whether the dissent and Justice Kennedy's approaches will withstand another voluntary desegregation case.

Whether those school districts have the will and the budget to continue with those race-sensitive plans remains to be seen. There does seem to be a possibility that a school district could change race-based plans to incorporate the kind of elements Justice Kennedy was talking about in his concurrence. The question is: What is the cost of implementing strategic building of schools in areas that would draw from integrated areas, doing targeting recruitment of students and teachers, or allocating resources for special programs? Time will tell whether school districts in America are willing to pay the price. Considering that,

While the Supreme Court decision creates new challenges for school districts that wish to foster diversity in local schools, it leaves room for new methods that preserve or create integrated educational opportunities benefiting all students. (MALDEF \& CRP/ PDC, 2008, p. 7)

\section{Practical Implications for Middle and Secondary School Principals as School Leaders}

Given the context of the Seattle/Louisville decision, this section addresses practical implications for middle and secondary school principals as school leaders who must deal with the outcomes produced by school district policies dealing with school integration plans. This section proffers discussion on two issues: (a) the role of middle and secondary school principals as school leaders who must deal with students, teachers, and parents within the context of the Seattle/Louisville decision and (b) the school principal's ability to communicate the realities of the decision in discussions within and outside the school. The considerations discussed here are important for school principals to understand and be able to articulate to their school stakeholders because of the mere fact that issues of student performance and achievement in our nation's public schools can be linked to schools being segregated.

Although middle and secondary school principals are typically not policy makers or make determinations about attendance zones and matters that determine where students attend public schools, school principals must deal with the outcomes produced by integration plans. In doing so, school principals serve as the first line of 
authority in communicating the information about school district policies and the impact of such policies on their school, teachers, students, parents, and the larger school community.

Note: The authors caution school leaders not to read into this section as prescription for dealing with the issue of school integration plans but as suggestions for practical implications and considerations for how middle and secondary school leaders can "unpack" the policy implications of their respective school district plan when it arrives at their doorstep.

\section{The Role of Middle and Secondary School Principals}

The role of middle and secondary school principals as school leaders who must deal with students, teachers, and parents within the context of the Seattle/Louisville decision should entail articulating and communicating the importance of this school legal issue that affects or can affect their school and stakeholders. Specific to the Seattle/Louisville decision is the need to communicate the nuances of how the school integration plan attends to or will attend to the diverse learning needs of all students and the emphasis of how teachers can effectively teach all students. One way to approach school integration, as Hawley $(2007$, p. 32) suggests, is by designing diverse learning opportunities (DLOs) for students to learn with and from individuals of different races and ethnicities. This, he notes, entails attention to two elements:

(1) It will have to be widely believed that schools that are genuinely integrated can (a) benefit students intellectually and enhance their future economic prospects and (b) contribute to the realization of valued social goals, such as the reduction of poverty and crime, in ways schools that are not racially or ethnically diverse cannot; and (2) Implementable strategies will have to be identified for designing DLOs in schools that predictably enhance the cognitive and social development of all students. (p. 32)

One can interpret what Hawley is suggesting as designing appropriate curricula with emphasis on structuring students' interactions with individuals different from themselves. He further notes, "Reasonably strong and extensive evidence exists on the efficacy of efforts to provide students with opportunities for productive interpersonal contact in DLOs" (p. 34). Hawley also posits that educators consider the courts interpretation "... to which race can play a role in drawing student assignment plans and promoting student and parent choices about school enrollment" (p. 39). Thus, he discusses four considerations for which educators can create and sustain effective integrated schools and classrooms:

- What is a productive mix of students of different races and ethnicities?

- At what grade level should integration begin?

- How can the diverse instructional needs of students be met without resegregating students within schools?

- Can extracurricular activities provide diverse learning opportunities? (p. 39) 
It is our suggestion that these important questions about school integration be heeded by school principals as the instructional/curriculum leader of their school. In the role of principal as instructional/curriculum leader, the principal should be educated and informed about school legal policy decisions, particularly if his or her school district already has a school integration plan in place or is looking to create a school integration plan. The questions posited by Hawley (2007) earlier should prompt school principals to look at the affective response of students, teachers, and parents to the plan and to consider the organizational school components (grade level, instructional time, curricular activities, etc.) of implementing an integration plan at their school site. The leadership functions of a middle or secondary school principal with regard to understanding, articulating, and disseminating information about the effects of the Seattle/Louisville decision on his or her school must include the recognition that he or she is the change agent for the success of any such school plan, even if he or she is typically not the policy maker with direct control over district policies and decisions regarding attendance zones and matters that determine where students attend public schools. As Rossow and Warner (2000) note, "The principal is the key factor in any change within the schools. Without support from the principal, it is unlikely that change will occur" (p. 285). Although Glatthorn and Jailall (2009) recommend that school principals recognize that ". . . leadership does not exist in a vacuum but is simply one component of effective organizational behavior" (p. 42), they further note that Aronstein and DeBenedictis (1988, as cited in Glatthorn \& Jailall, 2009) in their research identified five "enabling behaviors" of school principals that make a schoolwide difference in being an effective school leader:

1. Facilitating communication

2. Creating a positive, open climate

3. Building a vision with the staff

4. Developing staff through involvement

5. Being an effective and positive role model (p. 42)

In consideration and application of these so-called enabling behaviors (Aronstein \& DeBenedictis, 1988, as cited in Glatthorn \& Jailall, 2009, p. 42) of effective school leaders, we suggest that school principals should be receptive to (a) discussing the impact of the Seattle/Louisville decision with regard to the school's integration plan with the students, parents, and teachers of their school; (b) creating an open school climate to hear reactions to an existing or proposed integration plan by perhaps holding school forums to discuss what the school's integration plan entails; (c) building a shared school vision with the staff about the integration plan to achieve the objectives of integration, particularly how teachers can and will effectively teach all students with diverse learning needs - this should entail setting specific achievable school goals around sustaining an integrated school environment that involves 
the input and cooperation all school stakeholders: students, teachers, and parents; (d) assisting teachers to execute their instructional responsibilities in light of the school's existing or future integration plan; and (e) working with the school district to understand their specific responsibility as the school principal to carry out an integration plan and then being able to serve as the informed leader of their school. Hence, a school principal should be motivated to,

Implement curricula and instructional strategies that address the challenges and utilize the opportunities presented by diverse learning environments; . . Establish and nurture organizational capabilities and environments that promote the attainment of high academic standards and the development of positive dispositions and competences with respect to relations with diverse people; . . . Foster leadership that values and relentlessly pursues comprehensive strategies to maximize the unique learning opportunities possible in racially and ethnically diverse schools. (Hawley, 2007, p. 38)

\section{Communicating the Realities of the Seattle/Louisville Decision}

The school principal's ability to communicate the realities of the Seattle/ Louisville decision in discussions within and outside the school is imperative to being able to successfully implement a school integration plan at his or her school site. This communication entails engendering the cooperation of all school stakeholders. Hence, one can employ the notion, "Student learning in schools is shaped not only by what happens in particular classrooms but by the overall experiences that students have as they witness and engage in interactions with peers, teachers, school administrators, and staff throughout their school" (Hawley, 2007, p. 48). This notion should resonate in how school principals apply and put into effect an integration plan at their school site.

To be ready to handle the probability or reality of redesigning or creating a voluntary school integration plan, a school principal must think about his or her leadership role in the larger context of responding to and understanding the legal realities of the Seattle/Louisville decision. Such attention to the "larger context" of the school is not a new idea but part of the Educational Leadership Constituent Council (ELCC) standards for school-building-level and district-level leadership. There are seven ELCC standards with corresponding standard elements that pertain to educational leaders in the role as principals, superintendents, curriculum directors, and supervisors (National Policy Board for Educational Administration, 2002a). The explanation of ELCC standards can be accessed at http://www.npbea.org/ncate.php or by direct link to the PDF document athttp://www.npbea.org/ELCC/ELCCStandards\%20_5-02.pdf. Specifically, ELCC Standard 6 deals with the "larger context" and proposes that school leaders be able to understand, respond to, and influence the larger context. According to ELCC Standard 6 (National Policy Board for Educational Administration, 2002b): 
This standard addresses the need for educational leaders to understand and be able to operate within the larger context of the community and beyond, which affects opportunities for all students. ... Of vital importance is the ability to develop a continuing dialogue with economic and political decision makers concerning the role of schools and to build collaborative relationships that support improved social and educational opportunities for children. (p. 15)

But, how does this leadership standard relate to communicating the realities of the Seattle/Louisville decision? First, it is necessary for school principals to stay informed about what is occurring in their school district with regard to school integration plans. This may involve self-nominating to serve on a committee that is redesigning an existing plan or creating a new plan. It may also involve attending additional school board and/or district meetings to understand what is going on with integration.

Second, school principals should communicate with their district leader colleagues about what exactly and how exactly schools will be affected by an integration plan and be able to articulate how he or she as principal can realistically carry out the steps in the plan by discussing the availability of school resources, conducting a needs assessment, and/or outlining a plan of initiation if possible. "Interaction with district personnel and superintendents is crucial in helping to ensure that policies and resources are in place so the school's internal change climate can flourish" (Trail, 2000, p. 2). Further discussion within the school should perhaps consider issues such as the potential effects on teacher and student instructional time, possible curricular and pedagogical modifications, additional training or workshops that may be needed for teachers and parents to understand the effects of an integration plan at the school, and possibly holding school forums to clear up and/or address any misconceptions of an integration plan.

Third, a school is a reflection of the community in which it is located. Hence, school principals need to understand the local community and how it shapes the school's culture and values. In doing so, school principals should be ready to collaborate with the local community by working with parents and encouraging them to be involved in the school's curricula and teaching practices that may be affected by the integration plan. The notion of collaborating with family members of students affected by an integration plan, the school district, and the larger community may serve as a way to effectively implement an integration plan at one's school site. With regard to the concept of school leadership collaboration, Trail (2000) suggests,

The most immediate benefit of leadership as a collaborative effort is that principals not only share the lead, but share the load. . . . When leadership is "embedded in the school community as a whole," there is much greater potential for long-term sustainability of reform ... The sometimes overwhelming demands of being a principal make the strength that comes from shared leadership a vital resource. And in facing the demands that go along with implementing ... strength may be the most important characteristic for a principal to have. (p. 4) 
The importance of a school building leaders' ability to collaborate is highlighted in ELCC Standard 4 (National Policy Board for Educational Administration, 2002b) that reads:

This standard addresses the fact that cooperation among schools, the district, and the larger community is essential to the success for educational leaders and students. Educational leaders must see schools as an integral part of the larger community. ... Effective and appropriate communications, coupled with the involvement of families and other stakeholders in decisions, helps to ensure continued community support for schools. Seeing families as partners in the education of their youngsters, and believing that families have the best interests of their children in mind, encourages educational leaders to involve them in decisions at the school and district levels. (pp. 11-12)

Moreover, the Court's ruling on issues of school desegregation does indeed have an impact on the role of the school principal in understanding the decision and its implications for public schooling. As Drewry (1955) noted in his article on desegregation:

\begin{abstract}
Whatever the principal does in his school is done to promote the growth and development of all youngsters for constructive living in a democracy. The greatest resource we have for that purpose is the public school. . . In facing the problem of desegregation, school principals and teachers will be put to a real test of their loyalty and dedication to the public school system. (p. 17)
\end{abstract}

\title{
Conclusion
}

Perhaps a solution to creating voluntary school desegregation plans is to get out of the race-classification business all together. As Chief Justice Roberts contended, "The way to stop discrimination on the basis of race is to stop discriminating on the basis of race" (as cited in Burkholder, 2007, p. 29). The Wall Street Journal reported, "Nationwide, about 40 school districts with an estimated 2.5 million students use 'socioeconomic status' or SES, to help determine where students go to school" (Tomsho, 2007, p. B1). Income-based student assignment plans became popular in the 1990s. The basic feature of the plan is to limit the percentage of low-income students at any one building. The students are assigned by income stratification out of their neighborhood schools and bused to a higher income population building. In Raleigh, North Carolina, the Wake County Public Schools initiated such a plan in 2000 . It required that no more than $40 \%$ of the students in a building qualify for free or reduced-price lunches. Any percentage over the cap is treated as a transfer out. The student is reassigned to a building with a higher household income average.

Also, Wake County Public School administration reported that more than $80 \%$ of Black grade school students were reading at or above grade level. This is up from $57 \% 5$ years earlier. Of course the stated goals of the plans are to increase student 
achievement among low-SES students - not African American students. The legal result might be different if challengers to the plan were able to show that the SES approach is just a proxy for race classifications. Income-based student assignment plans are also used in Baltimore, Clark County Nevada, and San Francisco.

The use of SES to make student assignments does have an indirect desegregative effect. Thus far the courts have not challenged the use of SES in public school assignment programs. While direct use of race as a factor requires that strict scrutiny be met, SES seems to be closer to a "wealth factor," which the Court has decided is "quasi-suspect" in education. If the wealth factor or SES is only quasi-suspect, the plan may neither serve a compelling interest nor be narrowly tailored to the extent suspect categories require. Racial classifications are suspect categories requiring the government to show it can meet strict scrutiny. The Supreme Court has not required strict scrutiny in association with SES in the public schools (San Antonio Independent School District v. Rodriguez, 1973).

Furthermore, current discussion and action in school districts across the nation seem to signal that now is the time for school districts to reexamine student assignment plans and to consider both the immediate and long-term policy options of their respective or yet to be created integration plan. Recent 2008 publications such as "Still Looking to the Future: Voluntary K-12 School Integration: A Manual for Parents, Educators and Advocates" (NAACP LDF \& CRP/PDC, 2008) and "Preserving Integration Options for Latino Students: A Manual for Educators, Civil Rights Leaders, and the Community" (MALDEF \& CRP/PDC, 2008), coupled with the recent conversational panel in September 2008 and upcoming national conference in April 2009 on integration (see The Integration Report, Issue 13, 2008) should be a strong indicator to school leaders and educational policy makers that this topic of "school integration plans" indeed needs to be further understood in light of the interpretation of the Seattle/Louisville decision.

Also, research on future school and national demographic trends indicate that the U.S. population is moving toward a more diverse mixture of individuals where White Caucasian or Anglos will no longer be the majority racial category in the near future but will be in the minority - giving way to a tremendous increase in the Latino population in the years to come (see Keller, 2001; Lopez, 2006, for additional discussion). As Keller (2001) notes,

the need for more education among young Mexican-Americans is urgent because Mexican-American women have the highest birth rate of any ethnic group . . . and because the birth rate for Hispanic teenagers now exceeds that of Black teenagers. Though Latinos may soon become America's largest minority group. (pp. 225-226)

Additionally, the research done by Lopez (2006) on "The Impact of Demographic Changes on United States Higher Education 2000-2050" further points out the 
eventual decrease in the Anglo student population in K-12 schools. Lopez indicates,

Currently nearly 36 million Anglo students are enrolled in K-12 education, around 8.5 million Black students, and about 8 million Latino students. Projections for elementary and secondary students in 2050 show that the Anglo population in schools will actually decrease by about 6 million students, that Black students will gain around 5 million students, and that the Latino population will almost double its population to over 17 million students. Other students groups (primarily Asian) will gain nearly 5 million students by 2050 to total more than 8 million students. (p. 9)

These significant imminent shifts in the nation's demographics can presumably already be felt in some districts across the nation where great numbers of mixed racial students are attending public schools. As Lopez (2006) states, "The dramatic increases in the Asian, Latino and African American populations over the next 50 years will make [the] demographic make-up of the elementary and secondary schools look drastically different from anything we might even be able to imagine today" (p. 10). It is important for school leaders to consider this realistic change in the makeup of the U.S. population and consider the positive benefits of addressing/ designing voluntary integration plans now rather than waiting for a law such as No Child Left Behind (NCLB) to strong-arm school districts into taking proactive measures to implement such a school assignment policy with its intent of racial integration. Secondary schools have a great responsibility to groom and prepare young individuals both academically and socially to function in life as young adults in our diverse nation, hopefully having addressed the value of racial tolerance and interacting with different others in a democratic and civil manner. As the

courts have long acknowledged that public schools bear responsibility not only for instructing their charges in academic subjects, but also for instilling the democratic ideals that we collectively share and prioritize. As noted in Brown (1954) and Plyler v. Doe (1982), public schooling "has a pivotal role in maintaining the fabric of our society and in sustaining our political and cultural heritage." Among the most cherished American values, and at the very foundations of our constitutional principles, are racial tolerance and an abiding belief in and commitment to equality. Integrated schools advance these democratic values by providing meaningful opportunities to encounter, engage, and develop friendships with peers in other racial and ethnic groups. (MALDEF \& CRP/PDC, 2008, p. 11)

\section{References}

Burchyns, T. (2008, April 5). Napa schools to include economic status in attendance boundaries. TimesHerald. Vallejo, CA. Retrieved May 20, 2008, from http://nl.newsbank.com/nl-search/we/Archives? p_product $=$ VTHB\&p_theme $=$ vthb\&p_action $=$ search\&p_maxdocs $=200 \& s \_d i s p \operatorname{string}=$ allfields(Napa $\% 20$ schools $\% 20$ to $\% 20$ include $\% 20$ economic $\% 20$ status $\% 20$ in $\% 20$ attendance $\%$ 
20boundaries)\%20AND\%20date(all)\&p_field_advanced- $0=\&$ p_text_advanced- $0=($ "Napa $\%$ 20 schools $\% 20$ to $\% 20$ include $\% 20$ economic $\% 20$ status $\% 20$ in $\% 20$ attendance $\% 20$ boundaries") \&xcal numdocs $=20 \&$ p_perpage $=10 \& p \_s o r t=Y M D \_d a t e: D \& x c a l \_u s e w e i g h t s=$ no

Burkholder, Z. (2007, October 24). Because race can't be ignored [Electronic version]. Education Week, 27(9), 29-31.

Civil Rights Project/Proyecto Derechos Civiles (CRP/PDC) at UCLA. (2008, June 27). One year later: The Civil Rights Project/Proyecto Derechos Civiles at UCLA reflects on the anniversary of the Supreme Court's voluntary integration decision. Retrieved September 30, 2008, from http://www. civilrightsproject.ucla.edu/policy/court/voltint-anniversary.php

Cowan, A. L. (2008, April 5). New agreement is reached in Hartford desegregation. New York Times. Retrieved May 20, 2008, from http://www.nytimes.com/2008/04/05/nyregion/05hartford.html?_r=2\& ref $=$ nyregion\&oref $=$ slogin\&oref $=$ slogin

Drewry, G. N. (1955, October). The principal faces desegregation. Educational Leadership, 14-17. Retrieved March 22, 2009, from http://www.ascd.org/ASCD/pdf/journals/ed_lead/el_195510_drewry.pdf

Glatthorn, A. A., \& Jailall, J. M. (2009). The principal as curriculum leader: Shaping what is taught and tested (3rd ed.). Thousand Oaks, CA: Corwin Press.

Gratz v. Bollinger, 539 U.S. 244 (2003).

Grutter v. Bollinger, 539 U.S. 982 (2003).

Hawkins, H. (2008, April 1). D.M. schools allow fewer transfers. Des Moines Register. Retrieved May 20, 2008, from http://www.desmoinesregister.com/apps/pbcs.dll/article?AID=/20080401/NEWS02/ 804010377/0/NEWS09

Hawley, W. D. (2007). Designing schools that use student diversity to enhance learning of all students. In E. Frankenberg \& G. Orfield (Eds.), Lessons in integration: Realizing the promise of racial diversity in American schools (pp. 31-56). Charlottesville: University of Virginia Press.

Keller, G. (2001). The new demographics of higher education. Review of Higher Education, 24(3), 219-235.

Lehrer, J. (2006, December 4). Supreme court revisits race in public schools. Available at the PBS Online NewsHour Web site: http://www.pbs.org/newshour/bb/law/july-dec06/scotus_12-04.html

Lopez, J. (2006). The impact of demographic changes on United States higher education 2000-2050. Retrieved October 16, 2008, from http://www.sheeo.org/pubs/demographics-lopez.pdf

McFarland v. Jefferson County Public Schools, 330 F. Supp.2d 834 (W.D. Ky. 2004).

McFarland ex rel. McFarland v. Jefferson County Public Schools, 416 F.3d 513 (6th Cir. 2005), cert granted arg. tandum, Meredith v. Jefferson County Board of Education, 126 S.Ct. 2351 (2006).

Meredith v. Jefferson County Board of Education, 127 S.Ct. 2738 (2007).

Mexican American Legal Defense Fund (MALDEF) and Civil Rights Project/Proyecto Derechos Civiles (CRP/PDC) at UCLA (2008). Preserving integration options for Latino students: A manual for educators, civil rights leaders, and the community. Los Angeles: Regents of the University of California. Retrieved September 30, 2008, from http://www.civilrightsproject.ucla.edu/research/deseg/preserving integration_latino_children_2008.pdf

NAACP Legal Defense and Educational Fund, Inc. (LDF) and the Civil Rights Project/Proyecto Derechos Civiles (CRP/PDC) at UCLA (2008). Still looking to the future: Voluntary K-12 school integration: A manual for parents, educators and advocates. New York: LDF Communications Department. Retrieved September 30, 2008, from http://www.naacpldf.org/content/pdf/voluntary/Still_Looking to_the_Future_Voluntary_K-12_School_Integration;_A_Manual_for_Parents,_Educators_and_ Advocates.pdf

National Policy Board for Educational Administration. (2002a). Instructions to implement standards for advanced programs in educational leadership. Retrieved August 11, 2006, from http://www.npbea. org/ELCC/Instructions\%20to\%20ELCC\%20Standards.102.pdf

National Policy Board for Educational Administration. (2002b). Standards for advanced programs in educational leadership. Retrieved March 25, 2009, from http://www.npbea.org/ELCC/ELCCStandards\% 20_5-02.pdf 
Parents Involved in Community Schools v. Seattle School District No. 1, 137 F. Supp.2d 1224 (W.D. Wash 2001).

Parents Involved in Community Schools v. Seattle School District No. 1, 426 F.3d 1162 (9th Cir. 2005).

Parents Involved in Community Schools v. Seattle School District No. 1, 127 S.Ct. 2738 (2007).

Rossow, L. F., Connery, L., \& Schmitt, N. (2007, November 29). Limitations on voluntary school desegregation plans: The Seattle and Louisville cases. 224 Ed. Law Rep. 1, 21-40.

Rossow, L. F., \& Stefkovich, J. A. (2005). Education law: Cases and materials. Durham, NC: Carolina Academic Press.

Rossow, L. F., \& Warner, L. S. (2000). The principalship: Dimensions in instructional leadership (2nd ed.). Durham, NC: Carolina Academic Press.

San Antonio Independent School District v. Rodriguez, 411 U.S. 1 (1973).

Swann v. Charlotte-Mecklenburg Board of Education., 402 U.S. 1 (1971).

The Integration Report, Issue 13. (2008, September 22). Retrieved September 30, 2008, from http:// theintegrationreport.wordpress.com/

Thomas, W. C. (2008, April 10). Still a dream: Diversity an elusive goal as area schools remain largely segregated. Retrieved May 20, 2008, from http://www.commercialappeal.com/news/2008/apr/10/ still-a-dream-a/

Tomsho, R. (2007, June 29). More schools likely to spur diversity via income. Wall Street Journal Online, B1.

Trail, K. (2000). Taking the lead: The role of the principal in school reform. CSRD Connections, 1(4), 1-4. Retrieved March 22, 2009, from http://www.sedl.org/csrd/connections/oct00/oct00.pdf

Kathrine J. Gutierrez is an assistant professor in the Department of Educational Leadership and Policy Studies, Jeannine Rainbolt College of Education, at the University of Oklahoma. Her research interests include ethical and democratic leadership, curricular and instructional considerations for educational leadership preparation, organizational theory, and policy implications of legal school case decisions.

Lawrence F. Rossow is a professor in the Department of Educational Leadership and Policy Studies, Jeannine Rainbolt College of Education, at the University of Oklahoma. He also holds faculty rank in the College of Law where he teaches Education Law. Professor Rossow is the author of 13 books and nearly 100 articles on Education Law topics. 